\section{Sivistyminen on totuuden tavoittelua enemmän?}

Pihlström, Sami \& Kivistö, Sari (2018). Sivistyksen puolustus: Miksi akateemista elämää tarvitaan? Gaudeamus. 248 sivua.

TEOKSESSA OLLAAN suuren äärellä. Sivistyksen rapautuminen ilmenee yhteiskunnassamme kaventuneina käsityksinä hyvästä elämästä. Hyvän elämän tavoittelun välineistä on tullut päämääriä. Tehokkuuspyrkimykset, kilpailukyvyn parantaminen ja tuottavuuden maksimointi ovat yhteiskunnallisen keskustelun keskiössä.

Kirjoittajat - yleisen kirjallisuustieteen professori Sari Kivistö Tampereelta ja uskonnon filosofian professori Sami Pihlström Helsingistä - arvostelevat sitä, että nykyinen pelkistynyt sivistysajattelu muuttaa tiedon kauppatavaraksi, joka on mahdollista omistaa. Ja vieläkin enemmän: tiedosta tulee relevanttia vasta sitten, kun se on mahdollista muuttaa innovaatioksi ja siitä saatavaksi välittömäksi taloudelliseksi hyödyksi.

\section{KAVENTUNUT SIVISTYSKÄSITYS}

Tieto on siis turhaa, jos se ei tuota rahaa. Pohjimmiltaan kyse on siitä, että tieto on varteenotettavaa vasta sitten, kun sen legimiteetti osoitetaan itse tiedon ulkopuolelta. Kirjoittajat huomauttavat, että ennen valistuksen aikaa tiedon legimiteetti saatiin Jumalalta. Nyt tuo korkeampi taho on korvautunut markkinoilla. Oleellista on, että tieto itsessään ei riitä. Sillä on vain välinearvoa.
Arkihavainnot tukevat kirjoittajien havaintoa. Tilastokeskuksen kuluttajabarometrin mukaan suomalaiset kokivat, että maaliskuussa 2018 heidän käytössään ollut rahamäärä oli suurempi kuin koskaan aikaisemmin. Vauraudesta huolimatta keskivertosuomalainen suuntaa edelleen elämän parhaimmat voimat elintason parantamiseen, vaikka se ei enää elämänlaatua lisäisikään.

Vaurauden maksimointiin myös kannustetaan. Talouskasvupakko on vallalla oleva poliittinen normi edistystä tavoiteltaessa. $\mathrm{Pa}$ radoksaalinen arkihavainto on se, että ennennäkemättömästä vauraudestamme huolimatta toimimme yhä aivan kuin keskeisin huolemme olisi äärimmäinen köyhyys. Vaurauden lisääntymistä pidetään sivistyksen synonyymina.

\section{TOTUUTTA TAVOITTELEVA SIVISTYS}

Kirjoittajien mukaan ihmisen parhaat puolet esiin ottava ja kukoistamiseen kannustava sivistysyhteiskunta rakennetaan edelleen antiikkiin palautuvan tradition varaan. Sen mukaan itsessään arvokasta on totuuden tavoittelu kriittisen tieteellisen menetelmän avulla. Se tähtää periksiantamattomasti elämän ja maailman syvempään ja laajempaan ymmärtämiseen.

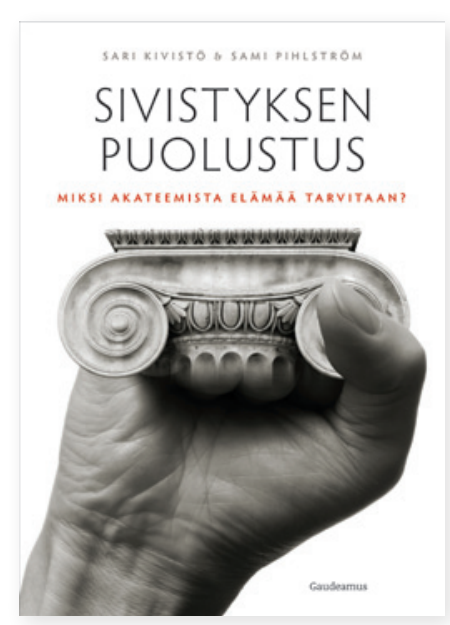

Moninäkökulmaisuus on kansalaisen ja yhteiskunnan sivistymisprojektissa keskeistä. "Sivistyksen ja akateemisen elämän kriisi on sen verran syvä ja vakava ettei sen enempää humanisteille kuin luonnontieteilijöilläkään ole varaa menettää toistensa tukea siitä selviytymisessä", kirjoittajat toteavat puolustaessaan tieteidenvälisyyttä.

Rakkauden ja kärsimyksen kaltaisiin ihmisen olemassaolon peruskysymyksiin keskittyvät kysymyksenasettelut ovat nekin edelleen ajankohtaisia. Ilmeistä on, että materiaalisen yltäkylläisyyden keskellä ihmisen tärkeimpiä ongelmia eivät enää ole nälkä tai kulkutaudit vaan elämän tarkoitusten ja merkitysten kirkastaminen.

Merkitykselliseksi koettua elämää kirjoittavat pitävät myös akateemisen tutkimuksen ydinkysymyksenä, sillä vain sen näkökulmasta "voidaan tuottaa kestäviä tieteellisiä tuloksia ihmiskunnan 


\section{SIVISTYS KURKOTTAA}

MENNEESEEN JA TULEVAAN.

hyväksi". Tieteellisen toiminnan ja siihen perustuvan koulutuksen perusta häviää, jos tutkijoilta hämärtyy käsitys siitä, miksi he ovat ryhtyneet tutkijoiksi. Olemassaolon syy jää silloin paikantumatta ja tunnistamatta.

\section{SIVISTYKSEN AJALLINEN KERROKSELLISUUS}

Jos ei ole tietoa menneisyydestä, ei ole mahdollista tavoitella objektiivisia totuuksia. Ja vieläkin enemmän: ilman tietoa menneestä nykyihmisellä ei ole mahdollisuutta etsiä totuuksia, mistä seuraisi tulevaisuuden toivon menettämistä.

Sivistykseen kuuluu siis väistämättä ajallinen kerrostuneisuus. Mutta samalla sivistys kurkottaa ennakkoluulottomasti uuteen. Tämän vuoksi sivistysyhteiskunnassa uutuus ja perinne kohtaavat, ja totuuspyrkimykset paljastavat ihmisyksilön ainutkertaisen elämän mittaamatonta arvoa ja ihmisen itsekkyyden liiallisen korostamisen turmiollisuutta, kirjoittajat toteavat.

Kirjan pääpaino on tietoon perustuvassa sivistymisessä. Haasteeksi kirjoittajat tunnistavat vallalla olevan kulttuurin, joka hukkaa totuuden tavoittelun inhimillisenä ideaalina. He nostavat tiedon rinnalle taiteen esimerkkinä itsessään arvokkaasta sivistyksen osa-alueesta. Samalla kirjoittajat viisaasti muistuttavat, ettei itseisarvoisten asioiden ja käytäntöjen puolustaminen sulje pois niiden välineellistä arvoa.

\section{SIVISTYS SUHTAUTUMISENA JA ASENNOITUMISENA}

Vähälle huomiolle Sivistyksen puolustuksessa jää se sivistys, joka ilmenee kansalaisen suhtautumisena ja asennoitumisena.

Aivan ilmeisesti tulevaisuudessa tarvitaan yhä enemmän huomion kiinnittämistä siihen, millaisesta asennoitumisesta ja suhtautumisesta syntyy ihmisen toimintatahto. Kuinka asetun omilla valinnoillani ratkaisijan rooliin ja miten tunnistan oman paikkani yhteiskunnassa? Mikä saa mielen ylevöitymään ja kuinka haltioidun elämästä? Tai kuinka rakennetaan toimeliaitten kansalaisten sivistysyhteiskuntaa?

Asennoitumisen ja suhtautumisen merkitys korostuu ajassamme siksi, että koulutussektoriamme läpäisevä osaamisperusteisuus on pohjimmiltaan vain olemassa olevan toisintamista varmistavaa.

Yhteiskuntarakenteiden murtuessa ja jakolinjojen vaihtaessa paikkojaan oman elämän tekijäksi tuleminen on huomattavasti olennaisempi elämän päämäärä kuin se, johon koulutussektorilla käytävä osaamiskeskustelu tähtää. Tämä korostuu hyvinvointiyhteiskunnassa, jossa keskeisin haaste ei enää ole äärimmäisestä köyhyydestä vapautuminen vaan se, että löytää pirstaleisessa maailmassa paikan, joka tuottaa syvää tyydytystä.

Aivan ilmeisesti tulevaisuudessa tarvitaan yhä enemmän sivistystä, joka kohottaa ihmisen täyteen arvoonsa. Kyseessä on samaan aikaan sekä yksilöllinen että yhteisöllinen prosessi. Ihminen ymmärtää itsensä osana muuta todellisuutta ja osaa toimia yhteisen edun puolesta. Huolenpidon piiriä pitänee laajentaa entistä aktiivisemmin ihmisyhteisön ulkopuolelle?

\section{ARTO O. SALONEN}

$K T$, apulaisprofessori Itä-Suomen yliopisto dosentti

Helsingin yliopisto 